\title{
DIAGNOSTIC AND THERAPEUTIC MANAGEMENT OF PATIENTS WITH ADRENAL INCIDENTALOMA
}

\section{DIJAGNOSTIČKE I TERAPIJSKE MERE LEČENJA PACIJENATA SA ADRENALNIM INCIDENTALOMOM}

\author{
Danica Bajcetić $c^{1}$, Slobodan Tanasković ${ }^{1}$,Vuk Sotirović ${ }^{1}$, \\ Marijana Jovanović ${ }^{1}$, Predrag Jovanović ${ }^{1}$, Petar Popov ${ }^{1,2}$, \\ Dragoslav Nenezici, ${ }^{1,2}$, Biljana Despotović, ${ }^{1,2}$, Đorde Radak $k^{1,2}$
}

\begin{abstract}
Summary
Routine and frequent use of computerized tomography (CT) angiography in vascular disease detection has led to frequent suprarenal gland abnormal findings that could, if undiagnosed, significantly complicate the course of the future treatment. The term adrenal incidentaloma refers to adrenal lesion discovered serendipitously during an imaging investigation. Adrenal incidentalomas do not constitute a single pathological entity. Major concerns are risks of malignancy and autonomous hormone secretion. The majority of all adrenal incidentalomas (approximately 79\%) are nonfunctioning benign lesions. Among functioning lesions subclinical cortisol excess is most frequently found. All patients with adrenal incidentaloma should undergo clinical, biochemical, and imaging evaluation for malignancy and hormone production. In this review, we discuss the current issues in diagnostic and therapeutic management of patients with adrenal incidentaloma. Follow-up of patients with adrenal incidentalomas involves the assessment of growth and development of hormonal function. After this review analysis several useful protocols could be designed to help vascular surgeons to adequately treat patients with concomitant vascular disease and adrenal incidentaloma.
\end{abstract}

Key words: adrenal gland, incidentaloma, tumor, autonomous hormone production, functional testing, imaging.

\section{Sažetak}

Rutinska i učestala upotreba kompjuterizovane tomografije (CT) angiografije pri dijagnostici vaskularnih oboljenja dovela je do čestog otkrivanja promena na nadbubrežnim žlezdama koje u značajnoj meri mogu kompikovati ishod lečenja ovih pacijenata. Termin adrenalni incidentalomi se odnosi na adrenalni leziju slučajno otkrivenu tokom imidžing procedura. Adrenalni incidentalomi ne predstavljaju pojedinačni patološki entitet. Najveća briga predstavlja rizik od maligniteta $i$ hormonske aktivnosti. Većina od svih adrenalnih incidentaloma (približno 79\%) su nefunkcionalne benigne lezije. Među funkcionalnim lezijama najčešće se susreću pacijenti sa subkliničkim kortizolskim ekscesom. Svi pacijenti sa adrenalnim incidentalomima trebaju biti podvrgnuti kliničkoj,biohemijskoj i imidžing evaluaciji za malignitet $i$ hormonsku aktivnost. $U$ ovom radu mi razmatramo aktuele dijagnostičke $i$ terapijske probleme vezane za pacijentesa adrenalnim incidenralomima. Praćenje ovih pacijenata obuhvata praćenje rasta $i$ hormonske funkcije adrenalnih incidentaloma. Nakon analiziranja ovog pregleda, moguće je napraviti nekoliko korisnih protokola koji bi pomogli vaskularnim hirurzima u adekvatnom lečenju pacijenata sa udruženim vaskularnim oboljenjima $i$ adrenalnim incidentalomima.

Ključne reči: nadbubrežna žlezda, incidentalom, tumor, nezavisna hormonska produkcija, funkcionalno testiranje, imidžing.

\section{INTRODUCTION}

Adrenal incidentaloma (AI) is an adrenal mass, generally $1 \mathrm{~cm}$ in diameter or larger, discovered through imaging study performed for indications other than evaluation of adrenal disorder. (1) Adrenal incidentalomas are found in the adrenal cortex or medulla and may be hormonally active or nonfunctional, malignant or benign. (2) The prevalence of AI at autopsy was found to be less than $1 \%$ in patients younger than 30 years old and up to $7 \%$ in patients aged 70 or older. (3) Imaging studies yielded similar findings: AI were found in approximately $2-4 \%$ of the middle aged, increasing up to more than $10 \%$ in the elderly, peaking between the fifth and the seventh decade. (4) Because of its increasing prevalence, AI is now recognized as a common clinical problem and has even been proclaimed as "endocrine epidemic of A-I-D-S" Adrenal Incidentaloma Discovered Serendipitously. (5)

The prospectively validated management of a patient with AI has not been established although a "state of the science statement" and Medical guidelines for the management of adrenal incidentalomas by have been published by the National Institute of Health and American 
Table 1. Etiology of incidentally found adrenal mass (adrenal incidentaloma)

\section{Adrenal cortical lesions}

Adenoma

Adenocortical carcinoma

Nodular hyperplasia

\section{Adrenal medullary tumors}

Pheochromocytoma

Ganglioneuroma/neuroblastoma

\section{Other adrenal tumors}

Myelolipoma, lipoma, lymphoma, haemangioma, hamartoma, teratoma

\section{Metastasis}

Lung, breast, kidney, gastrointestinal tract tumors, lymphoma, melanoma

\section{Infection}

Abscess, tuberculosis, fungi, cytomegalovirus

\section{Infiltration}

Amyloidosis, sarcoidosis

\section{Cysts and pseudocysts}

Parasitic, endothelial, degenerative adenoma

\section{Haemorrhage}

\section{Pseudoadrenal masses}

Stomach, pancreas, kidney, spleen, liver, vascular lesions (e.g. aneurysms and tortuous splenic veins)

Association of Clinical Endocrinologists and American Association of Endocrine Surgeons (AACE/AAES), respectively. $(6,7)$ The challenge is to recognize and treat an infrequent $\mathrm{AI}$ that involves a significant risk, either because of hormonal activity or because of its malignancy. (8) Adrenal incidentalomas do not constitute a single pathological entity. Etiology underlying incidentally discovered adrenal mass is presented in Table 1.

We will discuss the diagnostic and therapeutic approach in the following cases of AI: nonfunctional benign adrenal mass, hormone - secreting adenomas, adrenal nodular hyperplasia, pheochromocytoma and adrenal malignancy.

\section{Clinical approach in a CASE OF AI}

Nonfunctioning benign adrenal mass

Approximately $79 \%$ of all AIs are nonfunctioning benign lesions including adrenocortical adenoma, myelolipoma, ganglioneuroma and adrenal cyst. If functional screening is negative, the diagnosis is most likely nonfunctioning adenoma, the most frequently found adrenal tumor of all. (9)

Adrenocortical adenomas usually appear as non - highly vascular, homogenous lesions with smooth, encapsulated margins. In some isolated cases, these lesions progress to functioning tumors. (14)
Imaging studies cannot reliably distinguish between functioning and nonfunctioning adrenal adenomas. The second most commonly found benign adrenal mass is myelolipoma, a tumor consisted of fat and bone marrow elements. Due to its structure myelolipoma presents with characteristic imaging appearance. (9)

\section{Cortisol producing-adenoma}

Autonomous cortisol secretion was found in $5.3 \%$ of patients with AI. The autonomous cortisol production is referred to as subclinical hypercortisolemia because these patients lack full phenotypic manifestations of Cushing syndrome. However, these patients are more likely to suffer from obesity, hypertension, diabetes mellitus, and osteoporosis. (10) Patients with subclinical hypercortisolemia usually have normal values of morning cortisol level. However, disturbances in the circadian rhythm of cortisol excretion may occur in the form of slightly increased nocturnal cortisol concentrations. (11) Adrenal autonomy is best assessed by dexamethasone suppression test. The test consists of the administration of $1 \mathrm{mg}$ of dexamethasone ( $3 \mathrm{mg}$ of dexamethasone may be also applied) at $11 \mathrm{pm}$ followed by the measurement of morning serum cortisol concentration at $8 \mathrm{am}$. The result of cortisol level greater than $138 \mathrm{nmol} / \mathrm{L}(5 \mu \mathrm{g} / \mathrm{dL})$ is standardly used to define autonomous cortisol production. (12) The use of a much lower cut - off level of $50 \mathrm{nmo-}$ $1 / \mathrm{L}$ increases the sensitivity, but it also increases the rate of false positive results. (13) The result of $<1.8 \mu \mathrm{g} / \mathrm{dL}$ has been proposed as the best negative predictive value. 
The following tests can be performed either to confirm or rule out autonomous cortisol production: 2 - day high - dose dexamethasone suppression test, late - night salivary cortisol measurement and 24 - hour urinary free cortisol test. Cortisol value of $70 \mathrm{nmol} / \mathrm{L}$ measured after $2 \mathrm{mg}$ daily dexamethasone (for $48 \mathrm{~h}$ ) is used by some as a cut off value for identifying patients with autonomous cortisol secretion. (13) Low adrenocorticotropic hormone $(\mathrm{ACTH})$ concentration can be found in patients with autonomous cortisol production due to suppression. On the other hand, low dehydroepiandrosterone sulphate level may also be found as a result of insufficient ACTH production. Adrenal scintigraphy may be used for assessing lesion functionality.

A reasonable strategy is to consider adrenalectomy in younger patients $(<40$ of age), those with low ACTH levels, and in cases of autonomous cortisol production - associated obesity, hypertension, diabetes mellitus and osteopenia. A patient with subclinical hypercortisolemia should receive glucocorticoid therapy peri- and postoperatively because of the risk of acute adrenal insufficiency. $(1,14,15)$ Glucocorticoid therapy may last 6 to 18 months after unilateral adrenalectomy.(7)

Primary hyperaldosteronism: aldosterone - producing adenoma and adrenal nodular hyperplasia

Primary hyperaldosteronism is caused by aldosterone producing adrenal masses, mostly by adenoma or nodular hyperplasia. Adrenal nodular (micronodular or macronodular) hyperplasia may involve one or both adrenal glands and is more frequent than aldosterone - producing adenoma. Primary hyperaldosteronism is the most common cause of secondary hypertension while approximately $1 \%$ of adrenal incidentalomas have proved to be aldosterone - producing adenomas. $(1,9)$ Primary hyperaldosteronism should be suspected in the cases with early onset of hypertension, usually refractory to medication, and hypokalemia. However, these patients may have normal levels of potassium in the blood. The measurements of plasma aldosterone concentration (PAC) and plasma renin activity (PRA) are used to calculate PAC/PRA ratio (APR) which is the most commonly used test for screening of primary hyperaldosteronism. (16) The APR is most sensitive when blood is obtained $2 \mathrm{~h}$ after waking up in the morning, in upright position, after a brief period of rest. An elevated PAC (>20 ng/dL) and a high APR (>30) are highly indicative for hyperaldosteronism. (9) However, the cut-off for a positive result may be laboratory dependent. Thus, $\mathrm{PAC} \geq 15 \mathrm{ng} / \mathrm{dL}$ and $\mathrm{APR} \geq 20$ have also been used as indicators for aldosterone - producing adrenal masses. (1) The interpretation of test results should be noted in caution in patients receiving some medications including antihypertensives, and whenever possible, such therapy should be discontinued prior to testing. $(1,9)$ The negative suppression of aldosterone level after a salt challenge may be used as additional confirmatory test for primary hyperaldosteronism. (17)
When primary hyperaldosteronism is diagnosed it is important to determine the subtype of the disease. Patients with aldosterone - producing adenoma tend to be younger ( $<40$ years old), have more severe hypertension and hypokalemia, and have higher PAC than those with adrenal nodular hyperplasia. However, there is no specific biochemical evaluation that reliably differentiates the subtype of primary hyperaldosteronism. (9) The proposed therapy for aldosterone - producing adenoma is surgical (in patients with unilateral source of aldosterone excess). However, preoperative adrenal vein sampling is mandatory for surgical decision if CT scan shows bilateral or no lesions (especially in patients over 40 years old) to exclude bilateral adrenal hyperplasia that is treated with selective and nonselective mineralocorticoid receptor blockers. $(7,18)$

\section{Sex hormones-producing adenoma}

Sex hormone - producing adrenocortical tumors are rare and typically occur in the presence of clinical manifestations of autonomous hormone secretion. Routine screening for excess androgens or estrogens in patients with adrenal incidentalomas is therefore not recommended. (1)

\section{Clinically silent pheochromocytoma}

Approximately $4-7 \%$ of AIs have proved to be clinically silent pheochromocytomas. (19) These tumors may be benign or malignant. Even when clinically silent this tumor can be lethal. (20) In approximately $25 \%$ of patients, pheochromocytoma is associated with familial syndromes (multiple endocrine neoplasia type 2, von Hippel-Lindau disease), thus genetic testing should be performed, especially in young patient. (7)

Radiological findings indicative for pheochromocytoma consist of increased attenuation on unenhanced CT, prominent vascularity of the mass, delayed washout of contrast medium, and high signal intensity on T2 weighted MRI. (21) Biochemical assessment for pheochromocytoma is necessary in all patients with AI.

Measuring fractionated metanephrines and catecholamines in a 24 - hour urine are most widely used biochemical tests for diagnosis of pheochromocytoma. The additional measurement of fractionated catecholamines in the 24-hour urinary specimen is helpful in diagnosing dopamine - secreting pheochromocytoma. The measurement of plasma free metanephrines can also be used, but the value of this test is limited because of its low specificity. (22) The use of tricyclic antidepressants, decongestants, amphetamines, reserpine, and phenoxybenzamine should be discontinued to eliminate false positive results. Surgical resection should be performed in all patients with pheochromocytoma and $\alpha$-adrenergic blocking agent (phenoxybenzamine, doxazosin, or phenoxybenzamine/metyrosine) should be administered 1 to 3 weeks preoperatively. Long - term follow - up is advised because $10 \%$ to $15 \%$ of pheochromocytomas were found to be recurrent. (7) 


\section{Primary ADRENOCORTICAL CARCINOMA}

Primary adrenocortical carcinoma is a rare tumor with poor prognosis. The estimated prevalence of adrenal carcinoma in the general population is approximately 12 cases per 1000 000. (23) Among the patients with adrenal incidentalomas, adrenocortical carcinoma was found in $4.7 \%$ of cases. (10) Although adrenocortical carcinoma can develop at any age, a bimodal age distribution was found, with the disease peaking before the age of 5 and in the 4th to 5th decade of life. (2) This tumor is functional in two thirds of cases: hypercortisolemia either alone or in association with virilisation is the most frequent presentation. Estrogen- and aldosterone- secreting adrenal carcinomas are rarely found. $(8,24)$ The tumor size determines the risk of malignancy: adrenal cortical carcinoma accounts for $2 \%$ of AI up to $4 \mathrm{~cm}$ in size, $6 \%$ of tumors between $4.1 \mathrm{~cm}$ and $6 \mathrm{~cm}$ and $25 \%$ of tumors larger than $6 \mathrm{~cm}$. (25) Imaging methods are helpful in differing between adrenocortical malignancy and benign lesions. Using CT, higher pre-contrast attenuation values ( $>10$ Hounsfield Units) are usually obtained for malignant lesions because they generally contain less lipids in comparison to adrenal adenomas. After contrast administration, adrenocortical carcinomas present as inhomogeneous lesions with irregular borders and low percentage of contrast washout $(<40 \%)$. MRI and CT have comparable accuracy in differentiation between benign and malignant adrenal lesions.

Adrenocortical carcinomas usually present as hypointense lesions on both MRI T1- and T2-weighted images with strong enhancement after contrast injection and delayed washout. $(26,27)$ Adrenocortical carcinoma can also be visualized by positron emission tomography (PET). Open adrenalectomy is the procedure of choice in the treatment of primary adrenocortical carcinoma.

\section{Adrenal metastasis}

Adrenal metastases account for $50-75 \%$ of all AI in patients with history of malignant disease. Adrenal metastases are bilateral in $10-15 \%$ of cases, they are usually larger than $3 \mathrm{~cm}$ and most frequently originate from primary tumors of the lung, breast, kidney, gastrointestinal tract, and melanoma or lymphoma. Adrenal hypofunction may occur due to tumor growth. In addition to imaging techniques, CT - guided fine - needle aspiration biopsy may be applied. Pheochromocytoma should always be excluded before fine - needle aspiration biopsy in order to avoid the potential hypertensive crisis. (8) If PET is performed, most malignant lesions will show avidity for $\left[{ }^{18} \mathrm{~F}\right]$-fluorodeoxyglucose. However, it is difficult to separate primary adrenocortical carcinoma from adrenal metastasis by using PET scan.

\section{Follow-up of patients with AI}

Any adrenal mass with concerning imaging characteristics and/or lesions $\geq 4 \mathrm{~cm}$ should be surgically removed because of an increased risk of adrenal carcinoma. Follow - up of patients with adrenal incidentaloms involves assessment for growth and development of hormonal function.

The increase in size of a benign - appearing adrenal mass is used to screen for malignancy. Approximately $15 \%$ of AI increase in size during follow - up or may even shrink over time. There is no adrenal mass growth cut-off that can reliably confirm or exclude a malignant lesion. Patients with $\mathrm{AI}<4 \mathrm{~cm}$ and with radiologic characteristics consistent with benign lesions need to have imaging reevaluation at 3 to 6 months and then annually for 1 to 2 years.(7) However, some recommend first scan within 6 months followed by annual CT for up to $4-5$ years. Importantly, repeated CT scans increase the chance of causing fatal malignancy due to ionizing radiation. (8) If adrenal tumor grows $(\geq 0.8 \mathrm{~cm}$ or $\geq 1 \mathrm{~cm})$ and/or become hormonally active during follow - up, surgical removal should be considered. $(28,7)$

Hormonal evaluation should be performed at the time of diagnosis and then annually for up to 5 years. (7) The risk of hormonal progression was found to increase in the first 3 years and then remain stable. There is an opinion that hormonal follow - up in patients with non - functional $\mathrm{AI} \leq 2 \mathrm{~cm}$ is probably of limited value because these lesions rarely progress in size or become functional. (8)

THE IMPACT OF ADRENAL INCIDENTALOMA ON CARDIOVASCULAR PATHOLOGY

Patients with adrenal incidentalomas have been reported to have an increased risk for cardiovascular diseases. (29) Accordingly, subtle cortisol production was found to be an independent risk factor for hypertension in patients with AI. (30) Moreover, patients with subclinical hypercortisolemia were found to have increased prevalence of adverse metabolic and cardiovascular outcomes. (31) Increased prevalence of insulin resistance, a major risk factor for cardiovascular events, has been reported in patients with functional AI. $(32,33)$ Decreased insulin sensitivity was also reported in patients with nonfunctional AI. (34) Notably, patients with nonfunctional AI were found to have increased carotid intima media thickness. (35) and impaired cardiac morphology and function. (36) It has been suggested that some degree of adrenal autonomy that is not recognized by current methods, is responsible for increased cardiometabolic risk in patients with nonfunctional AI. (29) Accordingly, the level of in vitro steroid production was found to be similar in hormonally inactive adrenocortical tumors and subclinical hypercortisolism/overt Cushing syndrome suggesting cortisol autonomy in silent adrenal lesions. (37) Thus, increased prevalence of $\mathrm{AI}$ in patients with cardiovascular diseases is not only due to frequent use of imaging methods, but it is partly influenced by impact of AI on cardiovascular system. 


\section{CONCLUDING REMARKS}

According to the AACE/AAES guidelines, all patients with adrenal incidentaloma should undergo clinical, biochemical, and imaging evaluation for hypercortisolism, aldosteronism (if hypertensive), the presence of a pheochromocytoma, or a malignant tumor. (7) Surgical removal should be applied in lesions $\geq 4 \mathrm{~cm}$, pheochromocytoma, aldosterone producing - adenomas and unilateral nodular hyperplasia, cortisol - producing lesions with adverse clinical manifestations of hypersecretion, and in those with proved/suspected primary adrenocortical carcinoma. There is no definite recommendation for AI follow - up. Radiological reevaluation is advised in first 6 months, and then annually for $1-5$ years. Hormonal screening should be done annually for 5 years. However, hormonal follow - up may be questioned for non - functioning AI which is $\leq 2 \mathrm{~cm}$ in size. Surgical removal should be considered in patients with tumor growth $(\geq 0.8 \mathrm{~cm}$ or $\geq 1 \mathrm{~cm})$ and/or de novo hormonal activity. After this review analysis several useful protocols could be made to help vascular surgeons to adequately treat patients with concomitant vascular disease and adrenal incidentalomas.

\section{REFERENCES}

1. Young WF Jr. Clinical practice. The incidentally discovered adrenal mass. N Engl J Med. 2007; 356(6):601-10.

2. Androulakis II, Kaltsas G, Piaditis G, Grossman AB. The clinical significance of adrenal incidentalomas. Eur J Clin Invest. 2011; 41(5):552-60.

3. Grumbach MM, Biller BM, Braunstein GD, Campbell KK, Carney JA, Godley PA, Harris EL, Lee JK, Oertel YC, Posner MC, Schlechte JA, Wieand HS. Management of the clinically inapparent adrenal mass ("incidentaloma”). Ann Intern Med. 2003; 138(5):424-9.

4. Arnaldi G, Boscaro M. Adrenal incidentaloma. Best Pract Res Clin Endocrinol Metab. 2012; 26(4):405-19.

5. Griffing GT. A-I-D-S: the new endocrine epidemic. Journal of Clinical Endocrinology and Metabolism 1994; 79:1530-1.

6. NIH state-of-the-science statement on management of the clinically in apparent adrenal mass ("incidentaloma”). NIH Consens State Sci Statements. 2002;19(2):1-25.

7. Zeiger MA, Thompson GB, Duh QY, Hamrahian AH, Angelos P, Elaraj D, Fishman E, Kharlip J; American Association of Clinical Endocrinologists; American Association of Endocrine Surgeons American Association of Clinical Endocrinologists and American Association of Endocrine Surgeons Medical Guidelines for the Management of Adrenal Incidentalomas: executive summary of recommendations. Endocr Pract. 2009; 15(5):450-3.

8. Aron D, Terzolo M, Cawood TJ. Adrenal incidentalomas. Best Pract Res Clin Endocrinol Metab. 2012; 26(1):69-82.

9. Bittner JG 4th, Brunt LM. Evaluation and management of adrenal incidentaloma. J Surg Oncol. 2012; 106(5):557-64.

10. Young WF Jr. Management approaches to adrenal incidentalomas: a view from Rochester, Minnesota. Endocrinol Metab Clin North Am 2000;29:159-85.

11. Terzolo M, Bovio S, Pia A, Conton PA, Reimondo G, Dall'Asta C, Bemporad D, Angeli A, Opocher G, Mannelli M Ambrosi B Mantero F. Midnight serum cortisol as a marker of increased cardiovascular risk in patients with a clinically inaparrent adrenal adenoma. Eur J Endocrinol. 2005; 153:307-15.

12. Tsagarakis S, Vassiliadi D, Thalassinos N. Endogenous subclinical hypercortisolism: diagnostic uncertainties and clinical implications. J Endocrinol Invest 2006; 29:471-82.
13. Vassiliadi DA, Tsagarakis S. Endocrine incidentalomas - challenges imposed by incidentally discovered lesions. Nat Rev Endocrinol. 2011;7(11):668-80

14. Brunt LM, Moley JF. Adrenal incidentaloma. World J Surg. 2001;25(7):905-13

15. Papierska L, Cichocki A, Sankowski AJ, Cwikła JB. Adrenal incidentaloma imaging - the first steps in therapeutic management. Pol J Radiol. 2013; 78(4):47-55

16. Montori VM, Young WF, Jr. Use of plasma aldosterone concentration-to-plasma renin activity ratio as a screening test for primary aldosteronism. A systematic review of the literature. Endocrinol Metab Clin North Am 2002; 31:619-32, xi.

17. Stowasser M, Gordon RD: Primary aldosteronism - careful investigation is essential and rewarding. Mol Cell Endocrinol 2004; 217:33-9.

18. Pirvu A, Naem N, Baguet JP, Thony F, Chabre O, Chaffanjon P. Is adrenal venous sampling mandatory before surgical decision in case of primary hyperaldosteronism. World J Surg. 2014; Jan 31. [Epub ahead of print]

19. Nieman LK. Approach to the patient with an adrenal incidentaloma. J Clin Endocrinol Metab. 2010; 95(9):4106-13.

20. Lenders JW, Eisenhofer G, Mannelli M, Pacak K. Phaeochromocytoma Lancet $2005 ; 366: 665-75$.

21. Motta-Ramirez GA, Remer EM, Herts BR, Gill IS, Hamrahian AH. Comparison of CT findings in symptomatic and incidentally discovered pheochromocytomas. AJR Am J Roentgenol 2005; 185:684-8.

22. Pacak K, Eisenhofer G, Ahlman H, Bornstein SR, Gimenez-Roqueplo AP, Grossman AB, Kimura N, Mannelli M, McNicol AM, Tischler AS; International Symposium on Pheochromocytoma. Pheochromocytoma: recommendations for clinical practice from the First International Symposium. October 2005. Nat Clin Pract Endocrinol Metab. 2007; 3(2):92102

23. Koschker AC, Fassnacht M, Hahner S, Weismann D, Allolio B. Adrenocortical carcinoma - improving patient care by establishing new structures. Exp Clin Endocrinol Diabetes 2006; 114: 45-51.

24. Allolio B, Fassnacht M. Clinical review: Adrenocortical carcinoma: clinical update. J Clin Endocrinol Metab. 2006;91(6):2027-37.

25. Mansmann G, Lau J, Balk E, Rothberg M, Miyachi Y, Bornstein SR. The clinically inapparent adrenal mass: update in diagnosis and management. Endocr Rev 2004; 25:309-40.

26. 26. Johnson, P. T., Horton, K. M. \& Fishman, E. K. Adrenal mass imag ing with multidetector CT: pathologic conditions, pearls, and pitfalls. Radiographics 2009; 29:1333-51.

27. Outwater EK, Siegelman ES, Radecki PD, Piccoli CW \& Mitchell DG. Distinction between benign and malignant adrenal masses: value of T1-weighted chemical-shift MR imaging. AJR Am J Roentgenol 1995; 165(3):579-83.

28. Pantalone KM, Gopan T, Remer EM, Faiman C, Ioachimescu AG, Levin HS, Siperstein A, Berber E, Shepardson LB, Bravo EL, Hamrahian AH. Change in adrenal mass size as a predictor of a malignant tumor. Endocr Pract; 2010; 16:577-87.

29. Erbil Y, Ozbey N, Barbaros U, Unalp HR, Salmaslioglu A, Ozarmagan S. Cardiovascularriskin patientswithnonfunctionaladrenalincidentaloma: myth or reality? World J Surg. 2009; 33(10):2099-105.

30. Oki K, Yamane K, Nakanishi S, Shiwa T, Kohno N. Influence of adrena subclinical hypercortisolism on hypertension in patients with adrenal incidentaloma. Exp Clin Endocrinol Diabetes. 2012; 120(4):244-7.

31. Di Dalmazi G, Vicennati V, Rinaldi E, Morselli-Labate AM, Giampalma E, Mosconi C, Pagotto U, Pasquali R. Progressively increased patterns of subclinical cortisol hypersecretion in adrenal incidentalomas differently predict major metabolic and cardiovascular outcomes: a large cross-sectional study. Eur J Endocrinol. 2012;166(4):669-77.

32. Terzolo M, Bovio S, Reimondo G, Pia A, Osella G, Borretta G, Angeli A. Subclinical Cushing's syndrome in adrenal incidentalomas. Endocrinol Metab Clin North Am; 2005; 34(2):423-39.

33. Muscogiuri G, Sorice GP, Prioletta A, Mezza T, Cipolla C, Salomone E Giaccari A, Pontecorvi A, Della Casa S. The size of adrenal incidentalomas correlates with insulin resistance. Is there a cause-effect relationship? Clin Endocrinol. 2011 Mar;74(3):300-5.

34. Ivović M, Marina LV, Vujović S, Tančić-Gajić M, Stojanović M, Radonjić NV, Gajić M, Soldatović I, Micić D. Nondiabetic patients with either subclinical Cushing's or nonfunctional adrenal incidentalomas have 
lower insulin sensitivity than healthy controls: Clinical implications. Metabolism. 2013; 62(6):786-92.

35. Yener S, Genc S, Akinci B, Secil M, Demir T, Comlekci A, Ertilav S, Yesil S. Carotid intima media thickness is increased and associated with morning cortisol in subjects with non-functioning adrenal incidentaloma. Endocrine. 2009; 35(3):365-70.
36. Ermetici F, Dall'Asta C, Malavazos AE, Coman C, Morricone L, Montericcio V, Ambrosi B. Echocardiographic alterations in patients with non-functioning adrenal incidentaloma. J Endocrinol Invest. 2008; 31(6):573-7.

37. Midorikawa S, Sanada H, Hashimoto S, Suzuki T, Watanabe T, Sasano H. Analysis of cortisol secretion in hormonally inactive adrenocortical incidentalomas: study of in vitro steroid secretion and immunohistochemical localization of steroidogenic enzymes. Endocr J. 2001; 48(2):167-74. 